Perhaps the more appropriate term by which all this can be expressed, and which is sought for by Dr. Anstie, is "diversion," instead of "counter-irritation;" at least it has the advantage of being the shorter term. But to alter names is so inconvenient, that I think it far more important to acquire distinct perception of the truth, value, and meaning of terms before altering them.

Now 1 believe that all the measures which are comprised in the term counter-irritation consist in the infliction of an injury; and the beneficial result, when obtained, is effected by the corresponding diversion caused by the reparative process of that injury, whatever it may be. So that the point to study is what is the reparative process peculiar to each remedial injury; and then to suit the remedy to the malady.

In the term "remedial injury" everything used as counterirritant must be included, not omitting the mildest rubefacient.

When success attends the remedy, which I selected as an illustration, I assume that those forces, - namely of reparation-which are employed with energy upon the recent in jury, act by direct diversion from those forces which main tained the old disease : that bloodvessels there so long distended had become too feeble to contract and regain tone; but now obtain repose, and consequent vigour, by the diversion thus made in their favour, and that thus the cure is effected.

If the use of counter-irritation prove unsuccessful, it would argue to a certain extent the want of judgment with which it was prescribed-an argument applicable to remedies generally, for it is certain that if remedies of any description whatever gain general credit, they become unduly prescribed, of which fact, as an illustration, none is more remarkable than venesection, which had become so universally used that labouring men adopted it as a means of preserving health; - to use their own language, " always being bled spring and fall" with that object. Now, however, it has been generally abandoned, and would hardly be prescribed by anybody who could not from it confidently expect a very immediate, remarkable, and lasting benefit. It is no doubt just as good a remedy as ever, but is now only prescribed with more care and discrimination.

Great Marlborough-street, March, 1869.

\section{FATAL CASE OF POISONING BY OIL OF TURPENTINE.}

By PHILIP MIALL, Esq.,

SURGEON TO THE BRADFORD INFIRMART.

As there is not a single case of poisoning by oil of turpentine on record, perhaps the following notes may be interesting to the profession:-

On the night of Jan. 8th I was sent for to see an infant, aged fourteen weeks, supposed to have swallowed oil of turpentine. On arriving, at a quarter to twelve P.M., I found it comatose, pale, with extremely cold suriace, contracted pupils, slow aud irregular breathing (about three times in the minute); pulse quick, small, compressible, and almost imperceptible, but regular; and regular, feeble action of the heart. Auscultation disclosed mucous râles, and minute crepitation throughout both lungs. There was no excoriation on the face, lips, or mouth, and the mucous membrane was pale and cold. A strong terebinthinate odour came from the mouth, and the pillow on which the child had lain showed a large moist spot, smelling strongly of turpentine.

I tried artificial respiration by the Marshall Hall method for a quarter of an hour, without improvement; and as emetics were out of the question, the child not being able to swallow, and as the stomuch-pump, even if it could be applier to so young a child, could be expected to do little good, the poison having been taken nearly three hours before, I therefore gave up the patient as being in a hopeless condition.

According to the mother's account the infant had been left asleep, and well, at nine P.M. An hour afterwards she found it insensible, cold, and slightly convulsed. About half-past nine it was no iced by the grandmother to be cold, but, her sight being defective, she observed nothing further, and raised no alarm. A brother of eight years of age had been alone in the room with the infant, and it was ascertained that he was previously in the habit of drinking from medicinal bottles, and of inducing other children to do the same. A six-ounce bottle was found on the table without a cork, containing half an ounce of oil of turpentine, and the mother stated that before the accident it contained about twice that quantity. After being discovered, the infant was well enough to swallow a little milk. After I had gone, it was wrapped in warm blankets, as I had directed, and it remained in the same state until between three or four o' clock the next morning, when it is stated to have rallied a little and taken some milk. It soon became comatose again, and died at a quarter to twelve, nearly fifteen hours after taking the poison.

An inquest was held, but no medical evidence was taken, and no post-mortem examination could be obtained. I vaccinated the patient on the day of the accident, so that I know it to have been in good health at the time.

Feb. 9th, 1869.

\section{d e flitror}

OF THE PRACTICE OF

\section{MEDICINE AND SURGERY IN THE}

\section{HOSPITALS OF LONDON.}

Nulla autem est alia pro certo noscendi via, nisi quamplurimas et morborum et dissectionum historias, tum aliorum, tum proprias collectas habere, et inter se comparare.--Morgagn I De Sed. et Caus. MIorb., lib. iv. Procmium.

\section{NATIONAL HOSPITAL FOR THE PARALYSED AND EPILEPTIC.}

\author{
A CASE OF SYPHILITIC DISEASE OF THE \\ NERVOUS SYSTEM.
}

(Under the care of Dr. RAMseiLL.)

WE have watched with much interest the remarkable improvement under treatment of a man, aged forty, who came under Dr. Ramskill's care in January, 1868. He was a potman, sallow-faced, and unhealthy-looking, and he walked into the room with a feeble and staggering gait. There was external strabismus of the left eye, ptosis of the left lid, and occasional twitching of the facial muscles of the same side. These were the points first noticeable, and this was in a few words the history which Dr. Buzzard gathered of him:During the past eight months he has had four fits. The first in bed early in the morning: he lost his senses; was much convulsed; bit his tongue; the attack lasting for from fifteen to twenty minutes. The next two fits, of the same character, occurred one week after the first. The fourth took place a week after Christmas. Four months ago, he says, his left eye gradually turned outwards, and he saw double. Fourteen days ago he complained of great pain at top of head, and could not sleep for three nights. His left eye closed. His wife says he became very stupid, lost his memory, and has been getting gradually worse, so that now he is almost imbecile, requiring even to be dressed. He is deaf with the left ear, and, so far as can be gathered, the sight of the left eye is defective; its pupil is dilated and slugrish. He can whistle, and can close both eyes equally well, but there is ptosis of the left eyelid. His appetite is bad, and he is long in eating his food, which is retained for some time in his mouth ere he swallows it. The left arm is wasted to the elbow, and painful.

For a month or two after his first visit to the hospital it was not possible to obtain reliable information from him as regards syphilitic infection, which was strongly suspected. His mind was so vacuous that he only gave contradictory answers. However, he was at once treated upon this view. Ten grains of iodide of potassium were given three times 